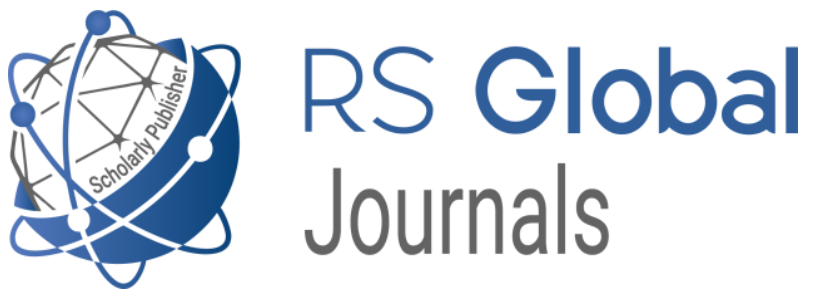

Scholarly Publisher

RS Global Sp. z O.O.

ISNI: 0000000484952390

Dolna 17, Warsaw, Poland 00-773

Tel: +48226022703

Email: editorial_office@rsglobal.pl

JOURNAL International Journal of Innovative Technologies in Social Science

p-ISSN

$2544-9338$

e-ISSN

2544-9435

PUBLISHER

RS Global Sp. z O.O., Poland

ARTICLE TITLE

EDUCATION LEVEL OF WOMEN AND MANIFESTATIONS

OF BIRTH RATE DECLINE: THE RELEVANT

CHALLENGES IN ARMENIA

$\operatorname{AUTHOR}(\mathbf{S})$

Meri Badalyan, Lusine Karapetyan

Meri Badalyan, Lusine Karapetyan. (2021) Education Level of

Women and Manifestations of Birth Rate Decline: the Relevant

ARTICLE INFO Challenges in Armenia. International Journal of Innovative

Technologies in Social Science. 4(32). doi:

10.31435/rsglobal_ijitss/30122021/7707

DOI

https://doi.org/10.31435/rsglobal_ijitss/30122021/7707

RECEIVED

06 October 2021

ACCEPTED

09 December 2021

PUBLISHED

15 December 2021

LICENSE

This work is licensed under a Creative Commons Attribution

4.0 International License.

(C) The author(s) 2021. This publication is an open access article. 


\title{
EDUCATION LEVEL OF WOMEN AND MANIFESTATIONS OF BIRTH RATE DECLINE: THE RELEVANT CHALLENGES IN ARMENIA
}

\author{
Meri Badalyan, PhD in Economics, Associate Professor, Dean of the Faculty of Accounting and \\ Auditing at ASUE, Armenia, ORCID ID: https://orcid.org/0000-0002-7128-1968 \\ Lusine Karapetyan, PhD in Economics, Associate Professor at the Chair of Business Administration, \\ ASUE, Armenia, ORCID ID: https://orcid.org/0000-0002-3894-4803
}

DOI: https://doi.org/10.31435/rsglobal_ijitss/30122021/7707

\section{ARTICLE INFO}

Received 06 October 2021

Accepted 09 December 2021

Published 15 December 2021

\section{KEYWORDS}

education level, work, women, birth rate, fertility rate, employment.

\begin{abstract}
This article is dedicated to the study of the interrelation between the education level of women and the birth rate. One of the essential lessons in the demographic history of the world countries is that the high birth rate recorded during the last century was temporary; it is already evident that the world birth rate has halved and tends to decline further. The level of education and employment of women are among the factors that underlie the decrease in the birth rate. Numerous studies prove that this relation is reversed. Like some other countries in the world, there is narrow reproduction in Armenia, which is mainly caused by changes in the education level, employment, mindset of women and their role in the family.
\end{abstract}

Citation: Meri Badalyan, Lusine Karapetyan. (2021) Education Level of Women and Manifestations of Birth Rate Decline: the Relevant Challenges in Armenia. International Journal of Innovative Technologies in Social Science. 4(32). doi: 10.31435/rsglobal_ijitss/30122021/7707

Copyright: (C) 2021 Meri Badalyan, Lusine Karapetyan. This is an open-access article distributed under the terms of the Creative Commons Attribution License (CC BY). The use, distribution or reproduction in other forums is permitted, provided the original author(s) or licensor are credited and that the original publication in this journal is cited, in accordance with accepted academic practice. No use, distribution or reproduction is permitted which does not comply with these terms.

Introduction. Globally, the key demographic issues are among the most pressing challenges of the late 20th century and early 21st century. According to Claire Harasty, Martin Ostermeier (2020) the data for the year 2020,72\% of developed countries are aged, and 79\% of developing countries are considered aging (p.6). As to the ILO's projections, this trend will continue in the future. Another reason for the aging of the population is the declining birth rate.

In recent years, Armenia has been classified among fast aging countries, mainly caused by the declining birth rate and the growth rate of emigration.

The published national and international demographic statistics, as well as numerous scientific researches on the mentioned issue, have shown that the birth rate is affected by the intellect, education level, social status, age at marriage, and a number of other factors. From those factors, this study is focused on the level of education and employment of women, since it directly affects a person's mental abilities, social status, age at first marriage, as well as the desire and willingness to have children.

Currently, the birth rate in Armenia has almost halved as compared to the 1990s, and the average age for marriage and motherhood has increased as well. Due to national and cultural specifics of Armenia, the role of education is especially emphasized here, including the right of women to get education. It should be noted that in Armenia, women possessing the first and second degrees of higher education outnumber men ${ }^{1}$.

\footnotetext{
${ }^{1}$ According to the RA Statistical Committee of the respective years of the Demographic Handbook of Armenia; https://www.armstat.am/en/?nid=82rding
} 
The purpose of this article is to study and analyze the impact of women's educational and employment levels on birth rates, as well as to identify their manifestations and challenges in Armenia.

Literature review. Max Roser's (It was last revised in November 2019, pp. 1-31) study found the following: In a number of countries, rapid population growth is a temporary phenomenon, as it ends when the average number of births per woman, i.e. the fertility rate, drops. In the present-day society, the problem of declining birth rate is largely acute and, according to forecasts, it will still be dropping further, covering larger areas. Population projections show that the number of births per year will remain around 140 million in the coming decades. Then, it is expected to decline slowly during the second half of the century. The world average fertility rate was 5 children per woman by the end of the 1960s, which has halved since the 1960s. As to the of the projections UNO, by 2100 the global fertility rate per woman will decrease (currently 2.5 ) to 1.9. Thus, the fertility rate tends to drop ${ }^{1}$.

Шапа, А. О., Ольвинская Ю. О. (2016, p. 94-102) in their research have highlighted that J. Bryant discussed in detail the most prevalent theories of demographic transitions. In particular, the author emphasized different aspects of the impact that the education level produces on the birth rate and substantiated the opinion that the birth rate is dropping along with the increasing significance of education since it affects the value system and socio-cultural values, which in turn influences the decision regarding the desired number of children in a family. In case of women, the interrelation between education and professional experience is of a dual character: despite equal rights to get education and achieve career growth, women's opportunities in the labor market are limited. It should be noted that this theory is gradually losing its significance as the average age of marriage in the world has increased and the birth rate has dropped.

In their scientific article, Архангельский В. Н., Зинькина Ю. В., Шульгин С. Г. (2019, p. 21 39) analyzed the level of female fertility in Russia, depending on the level of education; moreover, they classified women into two groups according to the education level: higher and incomplete higher, as well as secondary vocational education and lower. In the above-mentioned research, the authors made forecasts by three scenarios. By the year 2050 (probable scenario) the fertility rate for women with higher education will be 1.5 , and that for women with secondary vocational education and lower - 1.8.

According to Шапа, А. О., Ольвинская Ю. О. (2016, p. 94-102) in India, the analysts came up with the following formula: " $10 \%$ increase in women's education level leads to $0.5 \%$ decrease in total fertility. Thus, the Reproductive Health Report of India estimates that educated women in all South Asian countries marry 2-5 years later on the average.

According to a paper Elina Pradhan (2015, https://blogs.worldbank.org/health/femaleeducation-and-childbearing-closer-look-data) published by the World Bank, there are positive signs of declining birth rates in Sub-Saharan Africa. Statistics show that the higher a woman's level of education, the more likely she is to have fewer children. To put it otherwise, the negative correlation is more clearly observed between different levels of women's education and the total rate of fertility.

The mechanisms for the impact of education level on fertility have been established and described in detail in UNO's reports. Girls with a higher level of education are less likely to have unplanned pregnancies, since educated women start a family at an older age. There is a $10 \%$ drop in the birth rate for each additional year of education ${ }^{2}$.

The results of surveys conducted in the late $20^{\text {th }}$ and early $21^{\text {st }}$ centuries show that women in the world with higher education had 30\% fewer children on average than women with lower levels of education.

Thus, the higher the level of education, the lower the birth rate is. This ratio is absolute and axiomatic for any country in the world.

Materials and Methods. The research on the education level of women, the challenges of declining birth rates, and their manifestations in Armenia was accompanied by a comparative analysis of international and local professional literature. Considering the purpose of this article, the methods of comparative studies, general scientific analysis, grouping, and generalization were mainly applied. The source of information was the statistical data of ARMSTAT, ILO, UNO, World Bank, and other

\footnotetext{
${ }^{1}$ https://ourworldindata.org/future-population-growth\#the-wc-iiasa-projectionshttps://ourworldindata.org/futurepopulation-growth\#citation

${ }^{2}$ https://www.un.org/sustainabledevelopment/blog/2017/07/education-critical-in-preventing-adolescentpregnancy-underscores-un-agency/
} 
organizations and their relevant databases, official publications, and specialized scientific researches conducted in the sector.

Results and discussion. As it is known, sustainable development of society requires a dynamic rise in the number of highly qualified specialists, including scientists - people who are able to make discoveries and develop new knowledge in various fields. One of the national and cultural features of the society in Armenia is the overestimation of the role of education in the majority of Armenian families. Here, the right of both girls and boys to get higher education is equally emphasized. Although the mother's role in Armenian families is specific - devotion to the family and children, taking care of them and upbringing is very important, still, the role of the Armenian woman in the society has grown and is growing continuously, increasing the number of women holding high positions in the private and public sectors. Consequently, the interrelation between education, birth rate and employment is more apparent.

During the past decade, the share of women employed in the legislative, executive and judicial systems has increased considerably. In 2020, the share of women in the National Assembly was 23\%, while in 2010 it had been only 9\%. In 2020, the share of women Ministers dropped from 17\% in 2015 to $8 \%$ in 2020, but, in contrast to that, the share of women Deputy Ministers increased from $6 \%$ to $23 \%$. In 2020, as compared to 2015, the indices in the staff of the RA Ministries changed in favor of women, their share reaching 52\%. In 2020, the percentage of women judges was $28 \%$, while in 2010 it had been $21 \%$ (Table 1 ).

Table 1 . The ratio of women to men employed in the RA legislative, executive and judicial system, 2010-2020, $(\%)^{1}$

\begin{tabular}{|c|c|c|c|c|c|c|c|c|c|c|}
\hline & \multicolumn{2}{|c|}{$\begin{array}{c}\text { Members of the } \\
\text { National } \\
\text { Assembly }\end{array}$} & \multicolumn{2}{|c|}{ Ministers } & \multicolumn{2}{|c|}{ Deputy Ministers } & \multicolumn{2}{|c|}{$\begin{array}{c}\text { Staffs of RA } \\
\text { Ministries }\end{array}$} & \multicolumn{2}{|c|}{ Judges } \\
\hline & $\mathbf{W}$ & M & $\mathbf{W}$ & M & W & $\mathbf{M}$ & W & $\mathbf{M}$ & W & $\mathbf{M}$ \\
\hline 2020 & 23 & 77 & 8 & 92 & 23 & 77 & 52 & 48 & 28 & 72 \\
\hline 2015 & 11 & 89 & 17 & 83 & 6 & 94 & 48 & 52 & 25 & 75 \\
\hline 2010 & 9 & 91 & 10 & 90 & 10 & 90 & 35 & 65 & 21 & 79 \\
\hline
\end{tabular}

Women often have less professional experience because of their household duties or job interruptions caused by childbirth, which often makes them less competitive than men. However, amid increasing competition, the number of educated and highly qualified employees of both sexes is growing.

As we know, the reproductive age of women is $15-49$, i.e. the entire fertility period is 34 years. If we consider that higher education is completed at the average age of 22-24, it appears that the fertility period of those women already decreases by 7 to 9 years, compared to those getting no education at all. Besides, as we have already mentioned, women with higher levels of education get married later, possess more information, and have bigger family planning opportunities.

The dropping birth rate contributes to the understanding of the profound changes taking place in many countries around the world that account for the declining role of the family in terms of family size and structure. The size and structure of families are also influenced by cultural and social factors, such as late marriages, the number of people remaining single, and the rising divorce rate. These factors reflect the significant changes in values and lifestyles occurring in almost every country in the world.

According Хосни Зоаби (2017) disputes over women's career advancement is to the detriment of the family have turned more relevant since in many developed countries the number of women with higher education exceeds the share of men with higher education. Besides, it has become common for women to hold top positions - a fact that is also encouraged by the state policy of countries.

The correlation between women's employment and fertility has been analyzed by many authors, but there is still no clear definition of either the direction of this such correlation or its mechanisms, which is caused by the complexity of the impact produced by different factors. Women's employment is associated with reproductive views in two main areas. First, a woman earns income at work, which might affect her desire to run the household and have a certain number of children. Second, the fact that a woman works means that she has to combine her job and family, spending her time and vigor on both.

\footnotetext{
${ }^{1}$ The table was made by authors according to the RA Statistical Committee of the respective years of Women and Men in Armenia, Statistical Handbook.
} 
Numerous studies have shown that the drop in the birth rate is a result of economic progress and the increased access of women to education.

Analyzing the level of employment of women in Armenia by age groups, it becomes obvious that the level of employment of women in the 15-19 age group in 2019, as compared to 2009, increased by 3.6 percentage points and reached $8.5 \%$. The increase in the employment rate of women in this age group is due to the change in the perception of working that the current generation has. If 10 years ago many people of that age only studied, today the youth is striving to be more independent and is ready to combine education and work.

The employment rate for the 20-24 age group increased by 6.6 percentage points during the period under review, and by 3.2 percentage points as compared to last year. In 2019, the employment rate for women in the 25-29 and 30-34 age groups was 55.9\% and 59.2\%, respectively. And in 2019, as compared to 2009, the share of employed women in the 35-39, 40-44, as well as 45-49 age groups dropped by 3.9, 6.5, and 3.9 percentage points, respectively (Figure 1). This might be caused by the fact that, on the one hand, the average age of marriage and motherhood in Armenia has increased, and on the other hand, it might be the result of the drop in the population because of emigration or problems with getting employment in the labor market for women of the mentioned age groups (employers mainly prefer hiring people aged under 35).

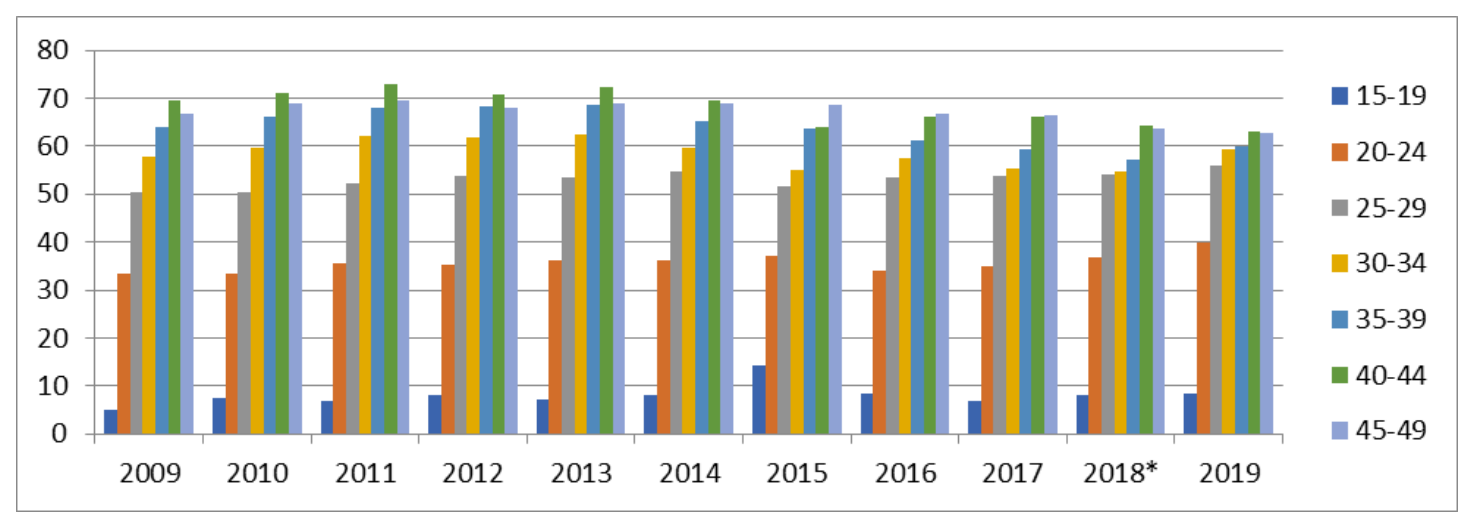

Fig. 1. Employment level by age groups, 2009-2019 (\%) ${ }^{1}$

Like in many other countries of the world, the number of children born per woman of the reproductive age has decreased in Armenia as well. While in the 1990s there was a rise in the rate of reproduction in the Republic of Armenia, since 2000 it has dropped in both rural and urban settlements. The fertility rate in 2019 was 1.6 (Figure 2).

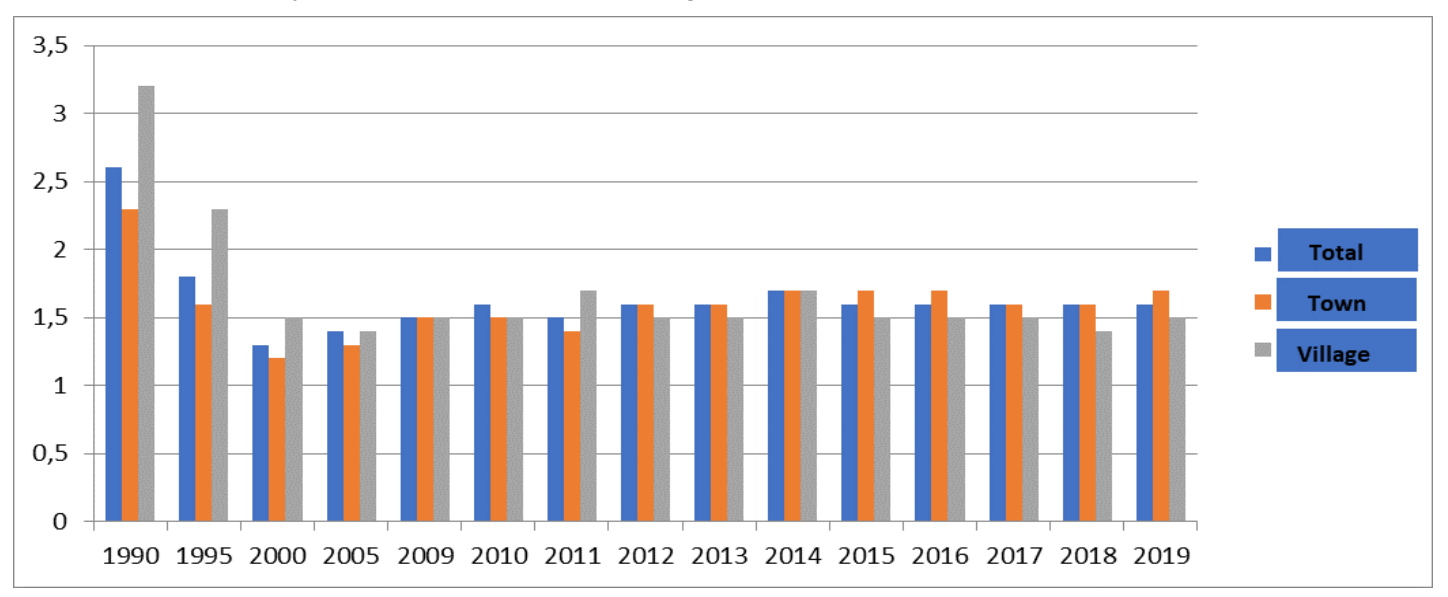

Fig. 2. Fertility rate in Armenia, 1990-2019

The number of women enrolled and studying at higher education institutions also decreased by around $40 \%$ during the period under review (Figure 3).

\footnotetext{
${ }^{1}$ The figure was made by authors according to the database of the Statistical Committee of the RA.

${ }^{2}$ The figure was made by authors according to the database of the Statistical Committee of the RA.
} 


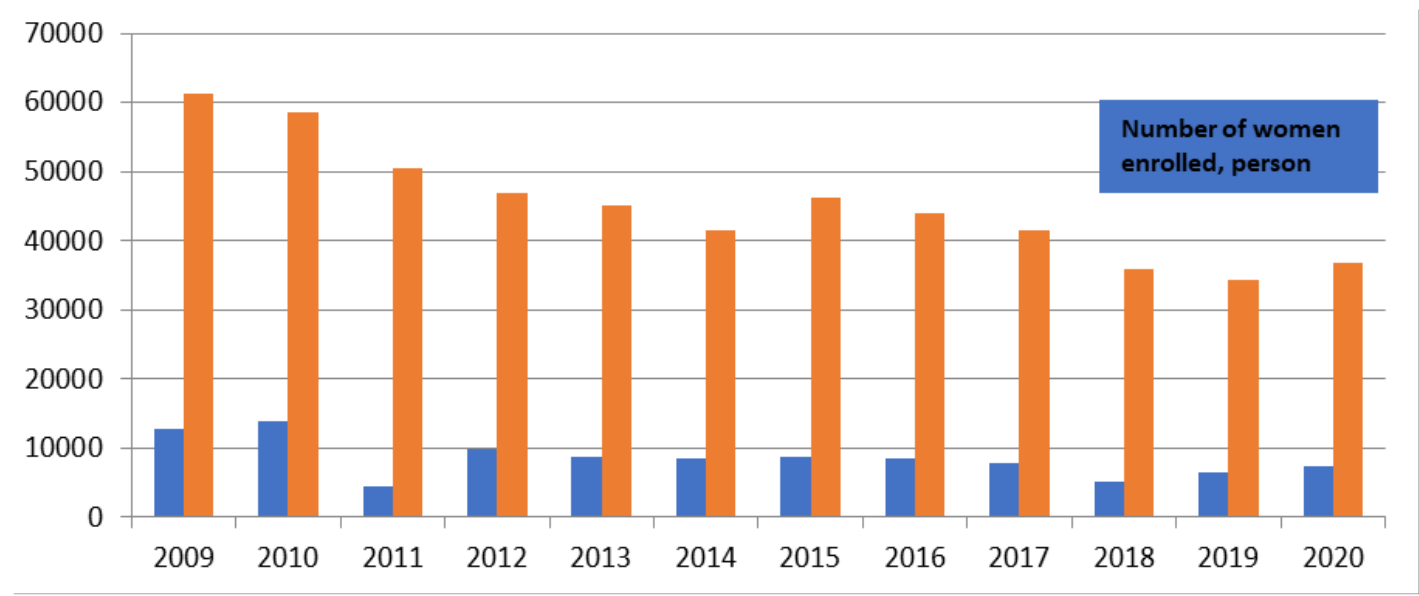

Fig. 3. Number of women enrolled and studying in higher education institutions, 2009-2019

In 1990-2019, the worst period in Armenia in terms of the total birth rate was the year 2000 - 10.6 permille, i.e. the above-mentioned index decreased almost twice as compared to 1990. Then, there was a slight upward trend, but in 2019, as compared to 2015, there was again a drop by 1.7 ppm (Figure 4).

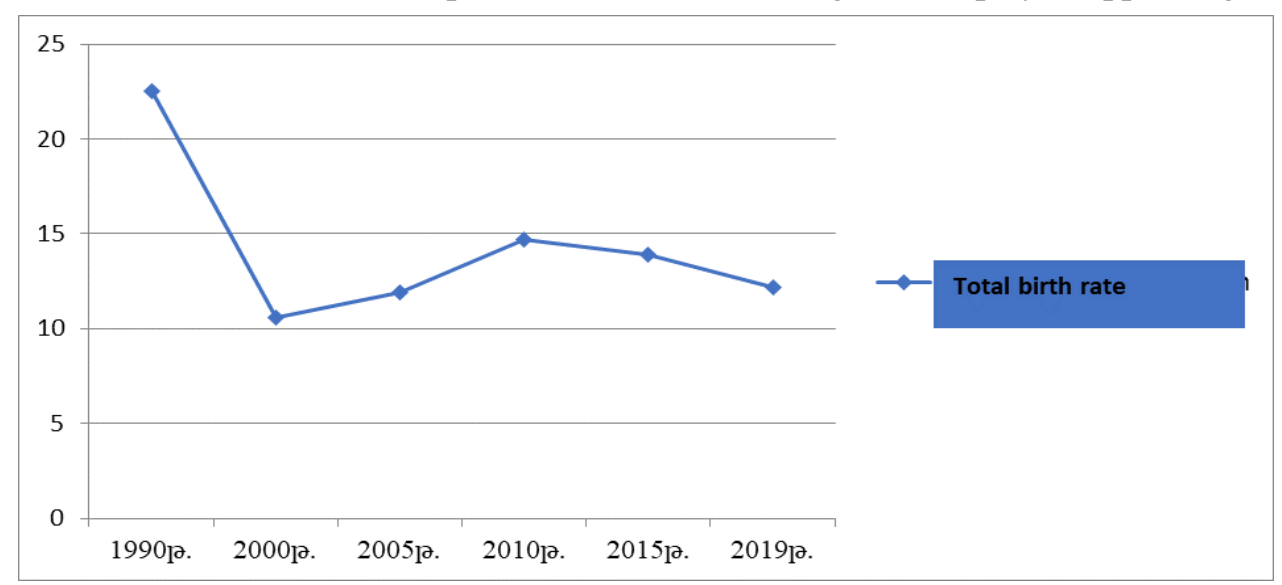

Fig. 4.

As we have already mentioned, during the past decade the average age of marriage and the average age of motherhood in Armenia increased - by 2.3 years in 2019 as compared to 2009 (Figure 5).

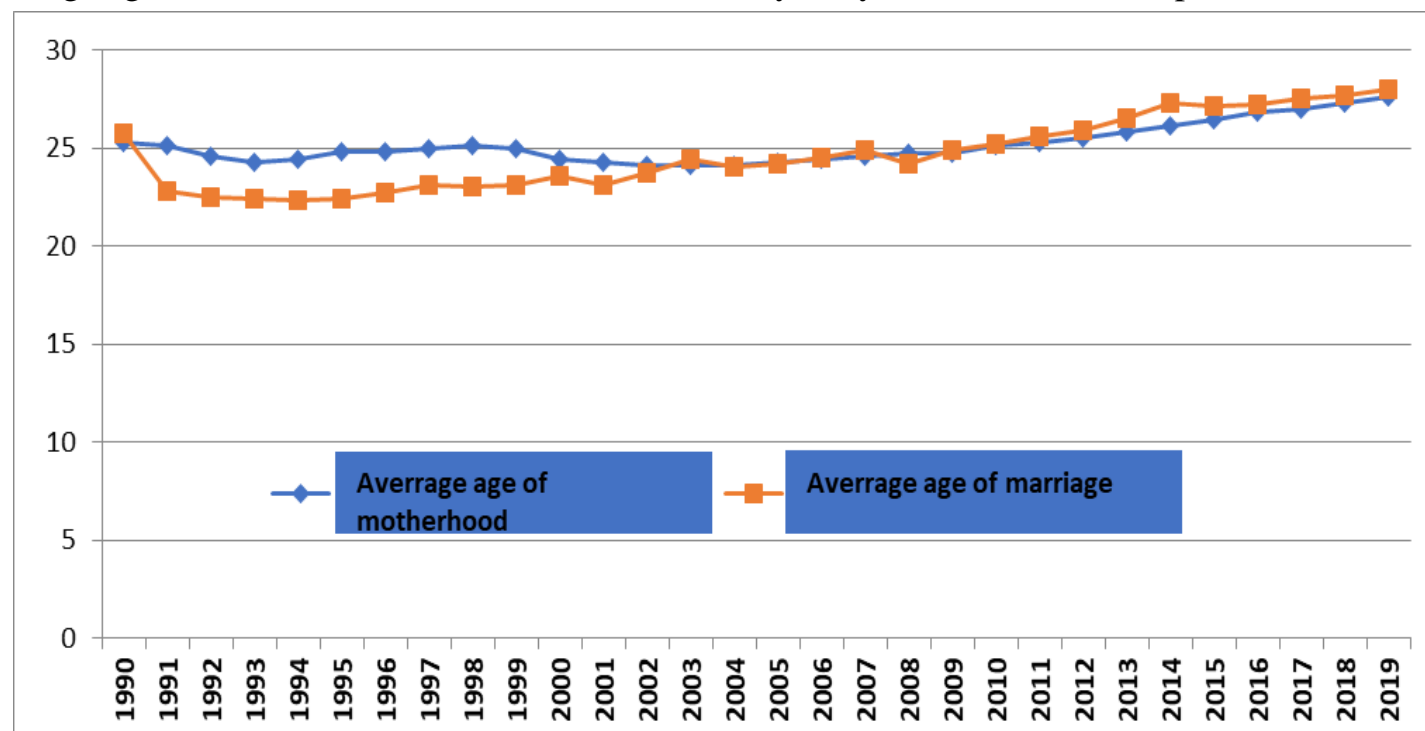

Fig. 5. The average age of marriage and giving birth in Armenia, 1990-2019

\footnotetext{
${ }^{1}$ The figure was made by authors according to the database of the Statistical Committee of the RA.
} 
Thus, we can conclude that the birth rate in Armenia has changed, which is explained both by the levels of education and employment, as well as the change in mentality and the role of the family.

Conclusions. Studies have shown that by the end of the 1960s the global average fertility rate was 5 children per woman, which has dropped twice since the 1960s. As to the UNO's projections, by 2100 the global fertility rate per woman will be 1.9 .

The study of the professional literature revealed that the birth rate is dropping along with the increasing significance of education since it affects the value system and socio-cultural values, which in turn influences the decision regarding the desired number of children in a family. Thus, we can assume that the higher the level of education, the lower the birth rate is. This ratio was observed in the studies of all countries. In 2019, as compared to 1990, the total birth rate in Armenia has halved. There is currently a narrowed reproduction in the country - the total birth rate is 1.6.

Although the mother's role in Armenian families is specific - devotion to the family and children, taking care of them and upbringing is very important, still, the role of the woman in the society has grown significantly and is growing continuously, gradually raising the number of women employed in the legislative, executive and judicial systems. Although the share of women has increased over the recent years, still it can be stated that on the average number of women holding senior positions is three times less than the number of men.

Besides, as we have already mentioned, women with higher levels of education get married later, possess more information and have bigger family planning opportunities. In Armenia, the average age of marriage and motherhood has increased by 2.3 years and the level of education of women is higher than that of men.

The dropping birth rate contributes to the understanding of the profound changes taking place in many countries around the world that account for the declining role of the family in terms of family size and structure. The size and structure of families are also influenced by cultural and social factors.

Disputes over women's career advancement being to the detriment of the family have turned more relevant since in many developed countries the number of women with higher education exceeds the share of men with higher education.

\section{REFERENCES}

1. Claire Harasty, Martin Ostermeier (2020), POPULATION AGEING: Alternative measures of dependency and implications for the future of work: ILO Working Paper, pp.53; https://www.ilo.org/wcmsp5/groups/public/---ed_emp/documents/publication/wcms_747257.pdf

2. Elina Pradhan (2015), Female Education and Childbearing: A Closer Look at the Datahttps://blogs.worldbank.org/health/female-education-and-childbearing-closer-look-data:

3. Max Roser (2019), Future Population Growth, https://ourworldindata.org/future-population-growth\#thewc-iiasa-projectionshttps://ourworldindata.org/future-population-growth\#citation

4. The Demographic Handbook of Armenia, https://www.armstat.am/en/

5. Women and Men in Armenia, Statistical Handbook, https://www.armstat.am/en/

6. Архангельский В. Н., Зинькина Ю. В., Шульгин С. Г. (2019) Рождаемость у Женщин с Разным Уровнем Образования: Текущее Состояние и Прогнозные Сценарии, (2019): Народонаселение. Том 22 № 1: https://cyberleninka.ru/article/n/rozhdaemost-u-zhenschin-s-raznym-urovnem-obrazovaniyatekuschee-sostoyanie-i-prognoznye-stsenarii/viewer

7. Шапа, А. О., Ольвинская Ю. О. (2016), Влияние образования на фертильность в условиях развития человеческого потенциала // Статистика - інструмент соціально-економічних досліджень: збірник наукових студентських праць. Випуск 2 - Одеса, ОНЕУ., 94 - 102, https://core.ac.uk/download/pdf/147041611.pdf

\footnotetext{
${ }^{1}$ The figure was made by authors according to the database of the Statistical Committee of the RA.
} 